the bye-laws, and in Clause 5 it is especially stated that the Council may admit Members as Councillors. Nor is there in the Draft Bill any clause which forbids Members from enjoying the privileges of the Councillors, among which is the election of the President. The question (4th) relating to Examiners not being elected from Councillors (originally the only persons eligible for examinerships) is certainly modified in the present Bill, but in the latter part of the 5th clause the question of the election of Examiners is touched upon in a way the real drift of which it is not difficult to see.

I enclose for publication the circular recently sent to the Fellows, and also an analysis of the answers returned, which shows that the Fellows generally are not desirous to share their rights with the Members, who, it must be remembered, may all attain to the Fellowship if they will.

At the next election of members of Council the votes will be given by proxy and in person. Let us hope that every Fellow will express by the vote he records his opinion whether the government of the College should be maintained in the hands of the Fellows or handed over to the body of Members at large. The responses to the circular enclosed pretty clearly indicate the predominant opinion of the Fellows.

Welbeck-street, May 20th, 1889. am, Sirs, yours truly,

C. STONHAM.

[Circular.]

The Proposed Alterations in the Government of the Royal College of Surgeons of England.

London, April 15th, 1889.

DEAR SIR,-In view of the present agitation by representatives of the Association of Members of the Royal College of Surgeons of England to obtain an Act of Parliament, the object of which is to make radical changes in the Constitution of our College, we shall be glad if you will favour us with your opinion on the following more important changes which would take effect if the Bill (the draft of which is published in

the Brit.sh Medi al Journal, March 9th, 1889) became law. Fellows would lose all privileges (except the titie
of Fellow) they now hold distinct from those of the Members. (Vide Sections 5, 16, 17, 26, \&c).

2. A meeting of Members could control the expendi-) ture of the College funds. (Vide Sections 8 ) and 9.)

3. The Members could elect any Member of twenty years' standing to be President or Councillor.

No member of the Council would be eligible for
an examinership. (Vide Section 40.)

Will you kindly write the word "Approve" or "Disapprove," as the case may be, against each of the four paragraphs, and return the paper as addressed at your earliest convenience. We shall also be glad to receive any remarks you may have to make with regard to the proposed Bill. We are, Sir, your obedient serrants,

EDWARD BFLLAMY, W. WATSON CHEYNE, F. LE GROS Clar H. H. Clu'tToN, N. DAYIES-COLLEY, GEORGE COWELL, CLINTON T. DENT, JOHN ERIC ERICHSEN, C. H. Golding-BIRD,
A. Pearce Gould,

HowaRD MaRSH, J. MCCARTHY,

RY MORRIS,

HERBERT W. PAGE, A. J. PEPPER, BERNARD PITTS, Challes STONHa Charles stonham, Fr. W. WAG TREVES, W. W. WAGSTAFFE.

Anatysis of Answers to the Questions set forth in the Circular. Total number sent out, 925 .

Returned filled up

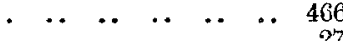

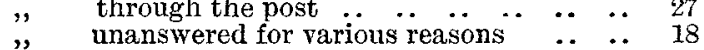

$\begin{array}{lllllll}\text { Total returnedl } & . & . & . & . & . & 511\end{array}$

Disap- Approve. Qualified Un-
prove. Tot. answered. Total. 1. Fellows would lose all prove. Approve. Qualifed answer. privileges (except the title of Fellow) they

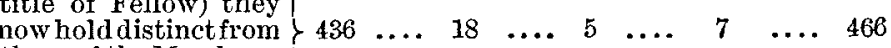
those of the Members. (Vide Sections 5, 16, $17,26, \& c$.$) .$

2. A meting of

bers could control the

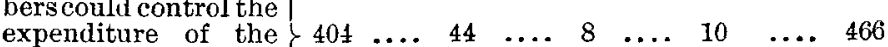

College Funds. (Vide College rands. (Vide

3. The Members could elect any Member of twenty years' standing to be President Section 3.)...

4. No member of the Council would be eligible for an examinership. (Vide)
Section 40.)

\section{DISPOSAL OF METROPOLITAN SEWAGE.}

\author{
To the Editors of THE LANCET.
}

Sins,-Strange as it may appear, in the controversy which has been carried on in your columns on this subject, no allusion has been made to the necessity of adopting some system of interception of the excreta (the solid portion) of urban populations at the fountain-head, this being the only means of preventing the drains and sewers, especially the former, being converted into underground cesspools. To effect this, it is absolutely necessary that separation of the liquid and soild excreta should take place at the starting. point, the latter being retained in sealed receptacles, while the former is allowed to flow away in pipes placed inside the main sewers; but in all cases the liquid excreta sewage must be kept quite separate and distinct from the rainfal sewage. It is idle to talk of the separation and precipitation of the solid excreta at the outfall under the presers system, since it is not there to separate; and if Dr. Corfield and Dr. Dupré, both men of great eminence, would nake, as I have made, a tour of inspection of the sewers, and take especial note of the sewers' storm outlets, through which about 90 per cent. of the solid excreta escapes during the rainfall and finds its way into the rivers, without reaching the sewers' outfall at all, they will find, with the present system, that precipitation or disinfection by any chemical process whatever is an impossibility. Surely we cannot cook our hare without first catching it, and that neither the Metropolitan Board nor any other board has yet accom. plished. We are constantly being told about the purity of the effluent; but this only proves the truth of my statement, that the solid excreta escape through the storm outlets during the rainfall; the amount that does reach the outfall may be 10 or possibly 15 per cent., but the frightful injury that is done to the health of the residents in the metropolis during the time the solid excreta is flowing or meandering, as it were, in such enormous masses to the storm outlets and the outfall under the streets and houses of London is sad to think of; and if it were possible to make an underground section horizontally of the great city and lift up the upper section, it would at once be seen whats a fearful amount of filth Londoners are living over and in the midst of. Does anyone suppose that the excreta of four million people could by any possible process be con. veyed to the outfalls or even to the storm outlets without giving off an immense amount of sulphuretted and phosphoretted hydrogen, ammoniacal, and other foul gases, which by contaminating the atmosphere of London must render it altogether unsuitable and unfit to support the lives of such an enormous number of inhabitants? The latter portions of the sewage question-viz, the pollution of the rivers and the waste of the finest fertilising agent known-will form suitable subjects for discussion when this most important question has been disposed of ; but it may easily be shown, under the present underground cesspoo system, that no solution whatever of the sewage problem has been effected, but that it has failed altogether, whether it is viewed in the light of a sanitary, an agricultural, or a financial question. I am, Sirs, yours \&ce.,

Birmingham, May 20th, $1889 . \quad$ E. CHESSHIRE, F.R.C.S.

\section{THE LOW RATES OF PROVIDENT MEDICAI CLUBS.}

To the Editors of THE LANCET.

SIRS,-A paper which I lately read on provident medical clubs at the West Midland Poor-law Conference at Malverm seems to have offended a writer in your pages (THE LANCET of May 18th, 1889, page 999). His comment is written in a very different spirit to that which, in my opinion, animates the enlightened and wide-minded medical men with whom I have had the privilege to come in contact and been in correspondence with. Does he forget that working men's benefit societies are attended by medical men at a similar rate and on similar principles to those of provident medical clubs and dispensaries? The mutual assurance principle on which they are worked is a sound one, and surely it were more reasonable to sketch out a better plan than to inveigh against a recognised one. Let him do this, and the working man will thank lim, and the ratepayers too. I deny, in fact, that the principle as put into practice either leaves the medical profession withont 